\title{
Voluntary counselling and testing for young adults in Limpopo Province - Counsellors' perceptions
}

\author{
Authors: \\ Patrone R. Risenga ${ }^{1}$ \\ Mashudu Davhana- \\ Maselesele $^{2}$ \\ Chikwelu L. Obi ${ }^{3}$ \\ Affiliations: \\ ${ }^{1}$ Department of Advanced \\ Nursing Science, University \\ of Venda, South Africa \\ ${ }^{2}$ Faculty of Agriculture, \\ Science and Technology, \\ University of North West \\ Mafikeng Campus, \\ South Africa \\ ${ }^{3}$ Academic Affairs and \\ Research, University of \\ Kwazulu Natal, South Africa \\ Correspondence to: \\ Mashudu Davhana- \\ Maselesele \\ Email: \\ mashudu.maselesele@nwu. \\ ac.za \\ Postal address: \\ PO Box 655, Giyani 0826, \\ South Africa \\ Dates: \\ Received: 04 Aug. 2011 \\ Accepted: 14 June 2013 \\ Published: 26 Sept. 2013 \\ How to cite this article: \\ Risenga, P.R., Davhana- \\ Maselesele, M. \& Obi, C.L., \\ 2013, 'Voluntary counselling \\ and testing for young adults \\ in Limpopo Province - \\ Counsellors' perceptions', \\ Health SA Gesondheid 18(1), \\ Art. \#615, 11 pages. http:// \\ dx.doi.org/10.4102/hsag. \\ v18i1.615

\section{Copyright:} \\ (C) 2013. The Authors. \\ Licensee: AOSIS \\ OpenJournals. This work \\ is licensed under the \\ Creative Commons \\ Attribution License. \\ Read online:

Counselling and testing services for HIV have long been a component of HIV prevention and care programmes in developed countries and have proved to be a cost-effective way of reducing risky behaviours. It is, therefore, important to document the perceptions of voluntary counselling and testing counsellors towards the use of counselling and testing amongst young adults. The purpose of the study was to describe the perceptions of these counsellors dealing with young adults in Vhembe District, Limpopo Province, where the study was conducted. Two themes emerged from the findings of the voluntary counselling and testing counsellors, namely that they feel that the programmes are inaccessible to young adults and that there are difficulties which might impact on the programmes' efficacy. The findings of this study should contribute to the reduction of HIV by promoting voluntary counselling and testing uptake by young adults.

Vrywillige berading en toetsing van jong volwassenes in die Limpopo provinsie-die perspsie van beraders. Berading- en toestingsdienste vir HIV is lankal reeds 'n geintegreerde deel van die voorkoming en versorgingsprogramme van HIV in ontwikkelde lande en dit is bewys dat dit 'n koste-effektieve manier is om gevaarlike gedrag te verminder. Dit is dus belangrik om die persepsies van vrywillige berading en toesting deur beraders ten opsigte van die gebruik van beraders onder jong volwassenes, te staaf. Die doel van hierdie studie was om die persepsies van hierdie beraders wat met jong volwassenes in die Vhembe distrik, Limpopo provinsie, werk, te beskryf. Twee temas het uit die bevindinge te voorskyn gekom, naamlik: dat die programme ontoeganglik vir jong mense is, en dat daar moontlike probleme is wat op die doeltreffenheid van die programme inslaan. Die bevindinge van hiedie studie behoort 'n bydrae te maak tot die vermindering van HIV deur die vrywillige berading en toesting by jong mense aan te beveel.

\section{Introduction and background}

Voluntary counselling and testing (VCT) is a key aspect of the South African government's strategy to prevent the spread of HIV. The government is committed to promoting and increasing access to VCT for people across the country and has created a policy framework for the increased uptake of VCT services in South Africa. Understanding the perceptions of VCT counsellors toward VCT, including misconceptions and fears about the process, is important if communication and advocacy campaigns are to be effective in encouraging people - more specifically, young adults, who are the future of this country - to be tested for HIV.

HIV testing is vital in order to access treatment after testing positive. Individuals and communities can cope with the spread of HIV by being informed properly, by assessing accurately the factors that put them at risk of infection and by acting to reduce the subsequent risks. VCT counsellors form the backbone of HIV services in South Africa. Whilst counselling may be perceived as being a 'nice-to-have' or 'soft' skill, its importance in prevention and treatment of HIV cannot be overstated. The South African government and its non-governmental organisation (NGO) partners have taken the lead in encouraging the sexually-active part of the population to know their status as part of basic healthcare. This is fundamental to living well - whether HIV positive or negative - as well as to ensuring early treatment if necessary. It also contributes to diminishing the stigma of HIV in society at large (ANOVA Health Institute 2012:2).

Health Services play a very significant role in ensuring that people of different ages in the communities are well informed and know what to do to curb the disease (Global Fund 2013:1). Young people are facing serious challenges when it comes to infections, with approximately $50 \%$ of all new HIV cases being seen in people aged 15-24 years. Almost 34 million people were thought to be infected with HIV at the end of 2011 worldwide, with two-thirds of them living in sub-Saharan Africa (Global Fund 2013:1). 
From a human-rights perspective, VCT can play a role in addressing both the stigma and the discrimination that are common with regard to HIV infection. Making VCT more accessible in order to enable people to know their status may help to break the 'circle of silence' and shatter the myths and misconceptions that fuel the pandemic. Access to VCT may make having an HIV test become more mainstream (WHO/ UNAIDS/UNICEF 2010:8).

\section{Problem statement}

Reduction and control of HIV in South Africa poses a great challenge and VCT/HCT (HIV counselling and testing) serves as the entry point. Proper utilisation of VCT services may lead to a reduction in the HIV-related mortality that is escalating in all the provinces of South Africa. To determine the impact of HIV in Limpopo, there is a need to look at the statistics for HIV prevalence and HIV-related deaths in the province. In 1990, the total number of HIV-positive people in Limpopo Province was 3050, with 31 people having signs of progression to AIDS and 19 HIV-related deaths (Dorrington, Bradshaw \& Bundlender 2002:18). When compared with the statistics for 2006, the problem in Limpopo Province with regard to HIV infection becomes all too obvious: there was a total of 396873 HIV-positive people, of whom 39474 had progressed to clinical AIDS and the total number of HIVrelated deaths had climbed to 121557 (Dorrington et al. 2006:70).

A study conducted by the United Nations Children's Fund (UNICEF2003:1) in South Africa has found that fewer than $50 \%$ of young adults know where they can be tested for HIV. For this reason, it is a good idea to help people learn more about VCT in order for them to be able to utilise the services that are available to them. There is no clear data reflecting the utilisation of VCT services by young adults in Limpopo Province, hence the question being asked by this study: 'What are the perceptions of VCT counsellors with regard to VCT use by young adults in Limpopo Province?'.

\section{Research purpose}

The overall purpose of the study was to describe the perceptions of VCT counsellors regarding VCT use by the young, with the aim of improving their perceptions and, hopefully, promoting the uptake of VCT by young adults in Limpopo Province.

\section{Definition of key concepts}

Acquired Immune Deficiency Syndrome (AIDS): This is the end stage of HIV infection where various diseases (mainly opportunistic infections) attack the weakened body (International Federation of Red Cross and Red Crescent Societies [IFRC] 2001:5; USAID/Family Health International [FHI] 2004:2).In this study, AIDS is used to indicate the stage of HIV infection where the CD4 + count has fallen below 200 and the body is infected by a variety of pathogens.

Counselling: Has been defined as being a confidential dialogue between a person and a care provider, aimed at enabling the person to cope with stress and make personal decisions (related, for the purposes of this study, to HIV infection). The counselling process includes an evaluation of personal risk of HIV transmission and facilitation of preventive behaviour and also involves pre- and posttest counselling (USAID/FHI 2004:2).This study defined counselling as being an interactive process between the counsellor and young adults in relation to taking an HIV test.

Follow-up counselling: Is defined as being the counselling offered to HIV-positive people in order to provide medical care as well as emotional- and social support after disclosing their results during post-test counselling (IFRC 2001:5). For the purposes of this study, follow-up counselling means interaction taking place between a counsellor and a young adult who is HIV positive with the aim of assisting them to cope with their HIV-positive status and thus helping them to utilise the HIV services available to them.

HIV negative: Antibodies were not detected during the test (IFRC2001:5). According to this study, it simply means the absence of detectable HIV in the bloodstream at the time of testing.

Human Immune-deficiency Virus (HIV): According to the IFRC, HIV is the virus that causes AIDS (IFRC 2001:5). This is not strictly true, as HIV is merely the virus that facilitates a progressive immune-compromised state in an individual, resulting in a weakened state that may progress to clinical AIDS. For the purposes of this study, therefore, HIV refers to the virus that weakens the immune system of an infected individual and predisposes said person to opportunistic infections.

Post-test counselling: The counsellor tells their client the result of the test and makes sure that the client understands both the result and its implications (IFRC 2001:5). This study defines it as counselling offered after an HIV test with the aim of giving HIV results to the young adults and helping them to understand the meaning of the results, whether negative or positive.

Pretest counselling: This includes a private session with a counsellor, who explains the testing procedure and how the results will be reported (USAID/FHI 2004:4). For the purposes of this study, it is the counselling given to young adults by a VCT counsellor before an HIV test.

Voluntary counselling and testing (VCT): Is a process by which individuals undergo confidential counselling in order to enable the individual to make an informed choice about learning his or her HIV status and to take appropriate action (USAID/FHI 2004:2).According to this study, this kind of counselling is given to young adults with the aim of showing them the importance of an HIV test and the benefits of early diagnosis.

A VCT counsellor: Is a person trained to offer VCT counselling to clients who present for VCT services (USAID/ 
FHI 2004:2). In this study, a VCT counsellor is defined as being a registered nurse who has been on a 10-day VCT training course and is able to offer VCT services.

Young adults: Males or females aged 19-35 years, regardless of their marital status.

\section{Significance of the study}

The knowledge gained through participation in this study may help in improving the young adults' understanding of VCT within the context of HIV infection. The study may also help the South African government with regard to planning activities in order to curb the pandemic. The findings from the study will hopefully inform policy formulation and review.

\section{Research methods and design Design}

Burns and Grove (2007:184) state that a research design is a blueprint of the method for conducting a study. It maximises control over factors that could interfere with the validity of the findings. For the purposes of this research, a qualitative design using exploratory, descriptive and contextual research was undertaken.

\section{Qualitative}

According to Fraenkel and Wallen (2006:430), the purpose of qualitative research is to conduct a study in the natural setting as the direct source of data, with the researcher as key instrument. The design used for this part of the study helped in the gathering of information meant to address the problems related to utilisation of VCT in Vhembe District, Limpopo Province.

\section{Exploratory}

According to Mouton and Marais (1998:43), the aim of exploratory research is to explore a relatively unknown research area in order to gain new insights into the phenomenon under study, rather than merely collecting accurate and replicable data. During this study, the researcher went to the natural settings of the VCT counsellors and explored their perceptions with regard to VCT use by young adults.

\section{Descriptive}

In descriptive design, emphasis is placed on in-depth description of a specific individual, situation, group, interaction or social object, where applicable (Mouton \& Marais 1998:43). During this study, VCT counsellors' understanding and perceptions with regard to VCT use by young adults were described.

\section{Contextual}

According to Mouton (1996:50), the aim of contextual research is to give extensive and in-depth description of the phenomenon, event or group within the context of the unique setting of the domain phenomenon. This study was bound contextually to the unique time, space and value context of the specific areas in Vhembe District, Limpopo Province, where the study was conducted.

\section{Population}

Population is the entire aggregation of cases that possess some common characteristics that are of interest to the researcher or, to put it differently, that distinct group of persons that meets the criteria that the researcher is interested in studying (Brink 1996:132; Cormack 1996:202). The population for this study is VCT counsellors trained in and offering VCT services in selected villages such as Xigalo and Mhinga in Vhembe District, Limpopo Province.

\section{Sampling}

The study sampling method utilised was non-probability sampling, wherein elements were chosen from the population using purposive sampling. Purposive sampling takes advantage of a group of subjects that fall within the population of interest and is conveniently accessible to the researcher based on knowledge of the phenomenon of study (Fraenkel \& Wallen 2006:100). Purposive sampling was utilised for the VCT counsellors based on specified criteria such as: being a VCT counsellor, being trained in VCT, offering VCT services in Vhembe district and working in specific selected areas within Vhembe District. Villages and clinics were selected purposively.

\section{Size}

Sample size depended on data saturation. Rubin and Rubin (2006:67) referred to saturation as getting similar data or ideas over and over again during the course of interviewing in a qualitative study. Saturation signifies completion of data collection in a particular phenomenon.

\section{Data collection methods}

Data collection is the gathering of information needed in order to address a research problem (Polit \& Hungler 1999:624). In this study, focus group interviews and field notes were used to collect data. The data were collected from April 2008 to September 2008.

\section{Focus group interview}

A focus group interview is an interview in which the respondents are a group of individuals assembled to answer questions on a given topic (Polit \& Hungler 1999:625). The focus group for this study consisted of five groups of participants, as summarised in Table 1. The focus group interviews helped to produce data that would be difficult to access via individual interviews. The interviews were conducted at the clinics because it was easy for the participants to access the venue and there was no need for transport. The participants were instructed to answer the 
TABLE 1: Summary of the participants interviewed.

\begin{tabular}{|c|c|c|c|c|c|}
\hline Type of participant & Sampling method & Sex & Age & Number of participants & Data collection method \\
\hline VCT counsellors & Purposive & Females & $31-34$ & 3 (1st group) & Focus group interviews \\
\hline VCT counsellors & Purposive & Females & $30-36$ & 5 (2nd group) & Focus group interviews \\
\hline VCT counsellors & Purposive & Females & $32-36$ & 4 (3rd group) & Focus group interviews \\
\hline VCT counsellors & Purposive & Females & $34-35$ & 3 (4th group) & Focus group interviews \\
\hline VCT counsellors & Purposive & Females & $30-36$ & 5 (5th group) & Focus group interviews \\
\hline
\end{tabular}

Note: Total number of participants were 20.

VCT, voluntary counselling and testing.

questions, for example: 'What are your perceptions towards VCT use by young adults?'.

\section{Field notes}

'Field notes' means describing as literally and accurately as possible that which is observed in the setting (Field \& Morse 1996:91). Personal and observational notes were used during the study. Personal notes included the personal details of participants, including their age. Observational notes included all the observations that the researcher recorded during the interviews in order to supplement the tape-recorded information. The notes included all of the information that the researcher had heard, seen, experienced and thought in the course of collecting data (Field \& Morse 1996:91). The researcher thus used field notes to describe their own reflections, feelings, ideas, moments of confusion and interpretations of all the events related to VCT, HIV and AIDS from the participants. A field diary was used for recording daily schedules and interviews, as well as direct quotations from the people in the setting, which proved useful later when reflecting upon the whole study.

\section{Data analysis}

Data analysis is the systematic organisation and synthesis of research data (Polit \& Hungler 1999:625). In this study, Tesch's eight steps of data analysis (Creswell 1996:155) were utilised. In each session, a tape recorder was used to record information and the information from the tape recorder was transcribed verbatim before data analysis. Following Creswell's guidelines (1996:155), the eight steps used during data analysis were as follows:

- Step one: Getting a sense of the whole. This involves reading through all of the transcriptions carefully. It may also involve jotting down ideas as they come to mind. The researcher went through all of the transcriptions carefully in order to make sense of the transcriptions.

- Step two: This involves picking up an interview document, checking the meaning and writing one's thoughts in the margin. The researcher picked one document (interview) and went through it in order to check the meaning.

- Step three: This step involves the development of topics after completing the checking of several interview documents. Similar topics can be clustered together and form columns that can be arrayed as major topics. The researcher formed topics from the data obtained and clusters were formulated for similar topics.

- Step four: Topics that had been formulated were abbreviated as codes and written next to the appropriate segments of the text and checking was then done in order to determine whether any new categories and codes emerged.

- Step five: This step entails finding the most descriptive wording for the topics identified and turning them into categories, whilst grouping topics that relate to each other and drawing lines to show interrelationships. Categories were formed from each theme developed.

- Step six: A final decision on the abbreviation for each category was made and codes were written alphabetically.

- Step seven: Data material belonging to one category were assembled in one place and preliminary analysis done.

- Step eight: Existing data were recoded.

\section{Ethical considerations}

\section{Permission to conduct research and ethical clearance}

Ethical considerations were adhered to in order to protect the participants. Ethical clearance was obtained from University of Venda, the clearance certificate (Ref: 4/2/2) was issued and later the proposal, together with the clearance certificate, was sent to the Provincial Department of Health and Social Development, Limpopo Province. The proposal was then presented to the Provincial Ethics office members and permission to conduct research was granted. Permission, together with a letter requesting further permission from the institutions, was later taken to hospitals in Vhembe District and the clinics.

\section{Informed consent}

Informed consent means that the participants have adequate information regarding the research, are capable of comprehending the information and have the power of free choice, thus enabling them to consent voluntarily to participate in the research or decline if they so wish (Polit \& Hungler 1993:359). In this study, the participants were informed with regard to the purpose of the research, procedures to be used in the research and the reasons therefor, their part in the research, the time and energy that the research would demand, as well as the possibility of pain, discomfort and stress (Jesani \& Barai 2000:25; Glesne \& Peshkin 1992:112; Strydom 2002:62).

\section{Confidentiality and anonymity}

Confidentiality and anonymity were ensured through the protection of the participants' identities. No names were linked with the information collected from participants 
in order to comply with issues of confidentiality (Jesani \& Barai 2000:29). Complete anonymity in this research was not possible, mainly because focus groups were used which makes conformity to anonymity very difficult. The sample size was also small and the researcher was involved in data collection, but participants' identities were protected and they were assured that their names would not be used after data analysis had been completed.

\section{Trustworthiness}

The goal of qualitative research is to represent accurately the participant's experiences. Lincoln and Guba (1985:74) suggested four criteria to indicate trustworthiness, namely, truth value, applicability, consistency and neutrality, which are relevant to the evaluation of the worth of research.

In this study, credibility was achieved through continual interaction (the researcher remained with the participants for five to six months during data collection) and through continuous consultation with the participants for their reflections (triangulation) (Brink 1996:124; Streubert \& Carpenter 1999:330).

The researcher addressed the issue of transferability in this study by providing sufficient descriptive data, peer review and triangulation to allow for transferability. Different methods of data collection were used to ensure triangulation, namely, field notes, focus group interviews. Confirmability was achieved by the use of peer review and data triangulation.

\section{Results and discussion of the findings}

Two main themes emerged from the interviews conducted with VCT counsellors. The question that was asked was the following: 'What are your perceptions with regard to VCT uptake by young adults as counsellors?'.

\section{Theme 1: Counsellors felt that the programme seems to be inaccessible to young adults}

The subthemes emerged from the themes following the process reflected in data analysis. VCT counsellors had both positive and negative feelings with regard to the VCT programme. During data analysis, four categories were identified from this theme. Each category has been supplemented with relevant quotations from the data and literature control(s) to support the findings.

\section{Counsellors perceive programme as being beneficial for young adults}

VCT counsellors perceive the VCT programme as being very important for young adults. Counsellors identified specific aspects which are supposed to be presented to young adults in order to promote VCT uptake. The following quotation reflects these perceptions:

'[The] VCT programme is a good programme to be attended by everyone, so VCT means that a person should dedicate himself/ herself, understands it and takes a step of going to qualified people who are nurses or lay counsellors at the clinics who are doing counselling in order to benefit from this programme. The person goes there to be tested in order to check if the virus for HIV is present in his/her blood. Is a good step and if he/she has discovered that the virus is present it will help them to plan for their future and the well-being of the family as well as checking on aspects to be followed and they will get specific information with regard to their help. Even if the results are negative and the virus is not present in their blood the person will know what type of life to follow in order to protect themselves so that they can stay without the virus. So it is a good step more specifically for young adults. So VCT services should always inform young adults about benefits of using VCT in order to motivate them and thus increase VCT use by young adults.' [P2, VCT counsellor at Xigalo, female, 32 years old]

The above quotation was supported by a statement by Kalichman and Simbayi (2003:442-447) which reflected that VCT is a cornerstone for early access to both prevention and care and support services in the area of HIV. It is a critical component of a comprehensive response to the HIV epidemic. VCT programmes need to be advocated and implemented at an increasing rate as they play an essentially constructive role in addressing a range of HIV-related problems and complications faced by the community at both the microand macro-levels. The majority of people living with HIV are unaware of their HIV status. High public awareness of HIV and knowledge of personal risk behaviours results in an increased level of caution and care. The protected (HIV negative) can be empowered to remain disease free and the infected (HIV positive) can be given access to medical and other support services that can help them to live longer, healthier lives and prevent transmission to others (Kalichman \& Simbayi 2003:442-447)).

\section{Integrating programme with other related services}

Other perceptions presented by VCT counsellors included the importance of collaboration of STI (sexually-transmitted infection)/HIV and tuberculosis (TB) services. This was identified as a step which can help vulnerable people to access a VCT programme and later assist them to get relevant treatment for conditions that are curable, such as being treated for other STIs whilst at the same time getting to know their HIV status:

'What I can say is that VCT, HIV, STI and TB are collaborated that is why in our STI services we say there is TB/HIV collaboration and every person coming with TB they are being counselled with regard to VCT even if they come with STI they are also counselled and if they agree they are tested. So anyone who is HIV positive they are being screened for TB and other STI and if they are found to be having TB and STI they are treated because TB and other STI can be cured even though the person is HIV positive. The programme will help young adults to get all the services in one place and maybe VCT use will increase for young adults.' [P1, VCT counsellor at Xigalo, female, 36 years old]

Integration of STI/HIV and TB services was developed in Brazil, indicating that VCT can be offered to people needing these services (Boswell \& Baggaley 2002:9). The integration can be helpful as most people present to health services for 
different reasons, meaning that integration of these services will promote accessibility of services to everyone. Integration of services is prevailing in South Africa although the process seems to be cumbersome (Boswell \& Baggaley 2002:9). Offering an integrated VCT service is believed to carry the possibility of increasing VCT uptake by young adults because when they visit these areas they will get all their services in one place.

\section{Provision of youth-friendly services}

VCT counsellors explained that promotion of VCT should still be encouraged to the young adults and youth through the use of national youth-friendly services everywhere VCT is offered, as this will help in VCT uptake by young adults:

'Firstly, to the young adults and the youth we need to make it a point that our services are youth friendly so that they will feel free to come to us that is why we have developed National Youth Friendly Services, to try and make youth to be friendly and we are also friendly to them so that they can come to us freely without any fears and that is where we are going to get a chance of teaching them about STI and the advantages as well as disadvantages of testing. But we also stress the issue of proper preparation for marriage as young adults so that they get into their marriage knowing their HIV status through the use of VCT services. So we need to win young adults because they are the generation of tomorrow, so if we can try by all means to make them understand to protect themselves more specifically from the virus of HIV we would have fought a good fight and thus VCT use will increase.' [P4, VCT counsellor at Xigalo, female, 30 years old]

Free VCT outreach programmes in the different areas where young adults are found have the potential to attract a large number of young adults, many of whom already have high knowledge of HIV risk factors and who probably only need some motivation from user-friendly services to get them to participate in VCT programmes. The use of people who are HIV positive may also help in increasing VCT uptake by young adults (Efuntoye et al. 2008:1).

\section{Counsellors viewed programmes as being inaccessible to young adults}

VCT counsellors mentioned some constraining factors that they felt hampered effective VCT service delivery amongst young adults. VCT services were viewed as being inaccessible to young adults. This leads to low uptake of VCT services and impacts negatively on the whole VCT programme. There are several factors identified by VCT counsellors which were believed to have a negative influence on VCT use by young adults.

\section{Lack of resources and availability of services}

The participants expressed the view that VCT services lack resources and are not available in more rural areas where young adults are found, such as farms.

Young adults working on farms are more difficult to contact because of such inconveniences as working times and lack of privacy in the mobile services in such areas, which affect VCT uptake by young adults in a negative manner:
'There are young adults whom VCT services have difficulty in reaching them [sic] like young adults who are working at the farms because from 08h00 till 17h00 they are busy working in the farms and this is also the time for mobile services so there is time clash. As nurses are busy conducting campaigns these young adults are faraway and we have difficulty of reaching them as most of them work since morning till sunset and they come home very late so these people if there is any other plan we would also try to reach them [sic]. I understand that there are mobile services for the people working in the farms but I believe that VCT services are not available at mobile clinics due to lack of privacy.' [P6, VCT counsellor at Xigalo, female, 33 years old]

Participant 8 , a 35 year old female VCT counsellor at Xigalo, reported:

'The mobile services available for farm workers that I know of, usually treat minor ailments and injuries that occurs during working and therefore rarely can VCT services be made available.'

A study conducted by Mfundisi et al. (2005:484) reflected that the available VCT services have difficulty in reaching the vulnerable young people, such as those who have experienced sexual abuse, drug- and alcohol abusers and hard-to-reach groups such as those working on farms, which poses a serious challenge to health professionals. The study indicated that there are few services developed to help young people in developing countries who are at increased risk of infection as a result of exposure, such as those working on farms.

The findings of this study presented similar problems, such as the inability of the health services to reach people working on farms. This inability is especially worrisome, given their lifestyle. Health services should respond to the needs of different groups in the community such as devising mechanisms of reaching farm workers.

Counsellors also indicated that human resources shortages lead to problems with regard to VCT services:

'Staff shortages have negative impact on VCT use by young adults. And the worst part is that as a VCT counsellor, you are not exempted from your other duties in the ward as a nurse apart from VCT counselling you are expected to do them both such as delivering women and you have never been for tea.' [P3, VCT counsellor at Xigalo, female, 31 years old]

In areas where there are staff shortages, clients are more likely to spend several hours waiting for VCT services, which could affect the quality of counselling offered. Instead of counselling being offered for 45 minutes, counsellors end up counselling people for less time and therefore fail to meet the necessary expectations of VCT. This may also be a contributing factor with regard to poor VCT uptake by young adults.

A study conducted by Kasonda and DeCelle (2008:6) reflected such common challenges in VCT centres as staff shortages in service areas, lack of confidentiality, lack of space and lack of provision of food, reported by both service consumers and provider. Baggaley (2001:24) reflected that being exposed to long waiting periods in order to access VCT contributed to 
the reduction of VCT use by young people, who often have a job to get back to. Health services were, therefore, viewed as being inefficient and they thus lost interest. This was reported whether the problem was due to lack of human resources or poor counselling services - both affected the VCT services in a similar negative manner.

Participants observed that the slow training offered by the government affects VCT uptake by young adults negatively as well as said training being offered to specific groups of nurses and not to other groups.

Participant 7, a 33 year old female VCT counsellor at Xigalo, reported:

'The other categories of nurses, such as auxiliary nurses and enrolled nurses are not trained. What is most surprising is that lay counsellors who do not know anything about nursing are being trained the criteria used to check who qualifies for training or not is not clear, and on the other hand there are professional nurses who are not yet trained because the process of training is too slow so not everybody is covered depending on the number that we are having. So this affects VCT use by young adults.'

According to a study conducted by Pronyk et al. (2002:7), all clinical staff were eligible to undergo VCT training in order to promote VCT use by the general population. In addition, prior experience clearly showed that offering training to junior staff alone could prove to be threatening to their senior colleagues and could potentially thereby undermine VCT services, having a further negative impact on VCT use by the people who need it.

There are no specific guidelines indicating who amongst the health professionals should be trained. Participants stressed that when looking at issues of confidentiality it would be appropriate for nurses and doctors to be trained as opposed to lay counsellors, because nurses and doctors have the professional background information related to confidentiality.

\section{Material resources}

Counsellors felt that the type of consent form designed for VCT, which was seen to be lacking certain aspects important for VCT and young adults, reflected an example of a lack in material resources. This lack might also lead to the omission of very important information related to VCT which was supposed to be given to young adults in order to motivate them to use VCT services and thus increase VCT uptake by young adults.

Participant 10, a 30 year old female VCT counsellor at Xigalo, said:

'Our consent form is not okay; it is having only four lines which show that a person is consenting. If there would be an attachment indicating issues to be discussed during pre-counselling and our responsibility would be to tick each time we have talked about all the points and this would definitely help in promoting the use of VCT by young adults. Such omissions leave much valuable information outside the consent form and because the counsellor is a human being at times they might forget to tell the young adults such valuable information necessary to motivate them to use VCT services and even to refer their friends and this affect VCT services negatively and thus lowers VCT use by young adults.'
A study conducted by Fylkesnes et al. (2000:43) indicated that consent forms need to be handled carefully when HIV counselling and testing is being offered, more specifically with regard to women attending antenatal care. It further reflected that authoritarian communication practices combined with well-meaning providers focusing on high acceptance rates seem to put these women in a difficult position, reflecting a negative use of VCT (Fylkesnes et al. 2000:43).

According to Sherr, Bergenstrom and Hudson (2000:307), the generally haphazard method of giving information and obtaining consent in antenatal HIV testing is probably counterproductive in terms of test uptake and the ultimate goal of minimising mother-to-child HIV transmission. In this context, the notion of consent is an important concept and informed consent as a reality needs to be examined carefully.

Long waiting periods for young adults to get antiretroviral drugs (ARVs) after they have been diagnosed as HIV positive whilst using VCT services is also a serious problem which could lower VCT uptake by young adults:

'Another challenge, if a person has tested positive, CD4 count taken and is expected to receive the treatment [sic] you find that the person will be given next year's date same time and when you look at home you would clearly see that this person next year won't reach it, because they say getting the treatment is not an emergency so you could see that according to his condition he is supposed to get treatment now but he is backward in the list [sic] and this makes young adults not to see the reason for testing and thus VCT use will be affected negatively.' [P12, VCT counsellor at Mhinga, female, 32 years old]

Baggaley (2001:60) cited that availability of treatment and ARVs is one of the barriers to VCT uptake. In countries where there is a lack of ARVs, medical and social support services for HIV-positive people, there is poor uptake of VCT. People don't understand why it is necessary to be tested, if in the end they will get nothing, even if they are found to be HIV positive (Baggaley 2001:60). Studies conducted in Europe and United States revealed that the death rate has fallen significantly due to the availability of ARVs, which has increased VCT use significantly (Carpenter et al. 2000:381).

\section{Theme 2: Difficulties which have a negative impact on the service rendered}

VCT counsellors indicated that there are many factors which have an impact on young adults. They indicated that the effects of HIV can have an indirect impact on young adults. The following subcategories illustrate the responses from VCT counsellors, together with their literature controls.

\section{Personal factors}

The following factors have been presented as being personal issues on the part of young adults which are seen as having a negative impact on VCT programmes. The subcategories that have emerged are elaborated on below.

Fear of needlestick injuries procedures and VCT uptake by counsellors: The counsellors indicated that the needlestick 
injuries associated with VCT could cause the services to be less accessible to young adults.

Participant 15, a 36 year old female VCT counsellor at Mhinga, said:

'Aspects such as the procedures to be followed when you have pricked yourself with a needle you used to withdraw blood from a patient you are just bound to be tested, if you are found to be negative you are given the ARVs or the post-exposure prophylaxis but if you are positive you are not given anything whereas there is a problem of repeated HIV infection because when you are given the treatment it prevents the virus to multiply and die before it gets into the blood.'

Fears regarding the reporting of needlestick injuries emanate from the fact that counsellors found to be HIV positive after a needlestick injury are not given the required prophylaxis. The government signed an agreement on 01 November 2001 in order to ensure that all public healthcare workers exposed to HIV by accidental needlesticks are guaranteed the right to State-sponsored tests and medication. This agreement obliges the State to carry out the cost of serological tests, preventive treatment and counselling services. It also states that the employee would be requested to leverage available access to HIV tests (Health Systems Trust 2001/02:1).

The findings reflect that VCT counsellors themselves are a barrier to convincing young adults of the safety of the test, because how can they manage to convince others if they are not themselves, as counsellors, convinced?

Counsellor frustrations: VCT counsellors indicated that management support contributes, either positively or negatively, toward VCT services.

Participant 19, a 30 year old female VCT counsellor at Mhinga, reported:

'Support is very minimal you can only see management people when they are expecting Provincial visit in your section telling you to prepare your things well indicating that they do not expect to see your section being horrible'.

Further to this, participant 7, a 35 year old female VCT counsellor at Xigalo, revealed the following:

'In my section you find that if there is no one to take the programme forward when you go off. So this constitutes a problem because there is no continuity of the programme because when you are on day duty there is no one on night duty, when you go off the programme has also gone home even though we leave the keys and all professional nurses are taught on how to code a patient in order to avoid the problem of missing HIV positive people. This affect VCT use by other young adults who are there in the ward as observers of the whole activity as it unfold and definitely sure they would not come for VCT services under such circumstances'.

Support for counsellors was identified as being one of the needs which would ensure supportive and ongoing supervision in order to promote VCT use by young adults. This should be coupled with frequent information updates, as well as acknowledgements of and education about emotional labour in counselling. Without constant support and incentives, counsellors may become less motivated and may come to perceive VCT as a burden (FHI \& USAID 2003:2).
Lack of support, either from management or other staff members, was identified as being detrimental to VCT uptake by young adults. Labelling of VCT services as being the domain of specific practitioners leads to the turning away of prospective VCT users who come for the services when those VCT counsellors are off duty, again having a negative effect on VCT uptake. This was also supported by a study conducted with regard to the effect of a shortage of VCT counsellors (FHI \& USAID 2003:2). Measures for dealing with such problems thus need to be made available in order to promote VCT uptake by young adults (FHI \& USAID 2003:2).

\section{Fear of counsellors regarding giving positive results to young adults}

Participants revealed that VCT counsellors are subjected to life-threatening behaviour on the part of young adults during and after counselling when they present HIV-positive results to these patients.

Participant 20, a 31 year old female VCT counsellor at Mhinga, indicated the following:

'As VCT counsellors we are faced with problems units such as firearms being produced by young adults after you have presented their HIV positive results, you find that because of the workload you forget to tell the client about the rules involved in contracting such as removing of dangerous weapons before counselling, so if you tell him that he is HIV positive, the client says to you that don't you think is wise for him to kill himself there and there and you are not sure whether he is going to kill you first before he kills himself. This type of behaviours [sic] makes it difficult for VCT counsellors to counsel young adults freely and therefore counselling will be coupled with suspicions and thus VCT uptake by young adults will be affected because once the counsellor loses interest in the process whatever will be done will be of poor quality.'

A study by Koopman et al. (2000:670) reported that a difficulty in coping amongst HIV-positive patients was ascribed to less income and a greater use of behavioural and emotional disengagement, impacting negatively on VCT use.

Phillips (1995:2) noted that most HIV counsellors suggested that the emotional responses displayed by clients, such as sadness, crying, lack of pleasure and suicidal ideation, provide the most important information for assessing depression in HIV-positive people. A therapeutic relationship based on trust, acceptance and tolerance was believed to be the cornerstone of successful management of such behaviours in order to promote VCT use by young adults.

Life-threatening behaviours displayed by young adults affect VCT counsellors, who then lose interest in the counselling sessions as they become suspicious and fear for their lives. This can then lead to poor VCT uptake by young adults who then view the VCT services as being of poor quality.

\section{Emotional burnout of counsellors}

VCT counsellors reported that they are exposed to emotional burnout as a result of their exposure to VCT services for young adults, which can also have a negative impact on VCT services. 
Participant 14, a 35 year old female VCT counsellor at Mhinga, reported:

'So hey, the programme well is okay but it leaves us being depressed to such an extent if you are a sympathetic person you end being drained and become a patient yourself, imagine if you counsel a 16 year old Para 0 Gravida 1 you find that after the test she is HIV positive you tend to ask yourself many questions such as what if the girl was my own daughter and actually start thinking about your own children at home. The worse part the boyfriend to the 16 year old in hospital when she is admitted the young boy is moving around with other young girls. And this makes you as a VCT counsellor to avoid counselling of young adults due to fears of associating them with your own children and thus VCT use by young dramatically drops.'

Sympathetic VCT counsellors may also find themselves drained and depressed after counselling and actually themselves become patients; most specifically when offering counselling to the youth and young adults with more or less the same age as their own children.

A study conducted by Richards et al. (2012:102) indicated that counsellors also experience negative emotions such as feelings of helplessness, inadequacy when counselling young people, over-identification with clients, conflict, anger, fear, sadness, anxiety, hopelessness, apprehension, frustration, horror, distress, irritation, ambivalence and shock. All of these experiences have been identified as being responsible for affecting their responses to VCT use by young people.

Frustration and depression experienced by VCT counsellors during and after counselling young adults impact negatively on VCT uptake by young adults because counsellors tend to associate young adults with their own children and hence lose interest in offering the counselling to these young adults and this lowers VCT uptake by young adults. Other counsellors, however, would want to counsel even more after these experiences, which could be something to foster when moving forward.

\section{Counsellors' perceptions of young adults' problems}

VCT counsellors indicated that there are problems affecting VCT use by young adults which are personal to the young adults themselves. Young adults' personal problems will be presented as subcategories in the following section:

Programme uptake and fear of abuse and rejection: VCT counsellors indicated that young adults are not using VCT services because of a fear of abuse and rejection which was believed to start within the health services and continued at home. This was expressed as follows:

'Others are afraid of the challenges people meet at home such as abuse and rejection, more specifically if person has tested positive. And the interfering in-laws when you find that a pregnant woman has chosen to use formula: in-laws tend to have many questions and many young people are afraid of that and this result in mixed feeding where a person will start to give the baby breastmilk and this is dangerous to the baby's life as the mother might be HIV positive and the baby will be exposed to the HIV virus as you all know that mother's breastmilk contains the HIV virus [sic] if a person is HIV positive.' [P18, VCT counsellor at Mhinga, female, 32 years old]
Participants commended pre- and post-test counselling as enabling them to accept their status and helping them cope with depression, stigma and thoughts of death. They emphasised the need for counselling to be continuous and not a onetime event (Nyanzi-Wakholi et al. 2009:905). A study of 245 women who were enrolled after pretest counselling and prior to the collection of test results in Tanzania found that disclosure of HIV serostatus was significantly higher for couples who discussed HIV testing prior to coming to the health centre (Maman et al. 2001:599).

Stigma continues to present one of the most influential and detrimental barriers to an individual's decision to test for HIV. According to Skinner and Mfecane (2004:160), stigma refers to a particular discrediting attribute which by its possession reduces and casts the individual as tainted and deserving of denigration. Stigma should be tackled in order to promote VCT uptake in health facilities.

\section{Lack of standardisation of procedures in South Africa}

Lack of standardisation of procedures in South Africa with regard to VCT and confidentiality has serious implications. Confidentiality has been identified as being one of the factors affecting VCT uptake by young adults because young adults seem not to be sure whether VCT counsellors will keep their results confidential or not. If young adults can be made to understand that their results will only be known to the relevant people until they are ready to disclose their status, VCT uptake would increase:

'In our Province, HIV results should be kept confidential and not to be shared with significant others of the client and that makes people to infect one another continuously because people are not aware about the status of the next person.' [P13, VCT counsellor at Mhinga, female, 36 years old]

Strachan et al. (2004:10) elaborated on issues related to procedures of ensuring confidentiality referrals by indicating that these promote responsibility for promoting shared confidentiality of client information amongst diverse service providers.

The International Planned Parenthood Federation (2005:48) reported that client information which is confidential and related to VCT should always be kept in a locked filing cabinet accessible only to counselling staff, as this helps in promoting VCT use by young adults.

The findings above reflect that VCT counsellors have different experiences regarding VCT uptake and the factors believed to have a negative effect on VCT use by the young. These experiences have been presented in the themes and subthemes above.

\section{Limitations of the study}

The study was conducted exclusively in Limpopo Province, amongst the few VCT counsellors of two selected villages in Vhembe District. True to the demographic scope and its attendant sample, the resultant findings are not amenable to wider generalisation. 


\section{Recommendations}

VCT counsellors should be counselled in order to be able to deal with the challenges they face on a daily basis when offering VCT services. Mechanisms for encouraging young adults to go and test themselves should also be put in place in order to promote VCT uptake. Conducting the same project in other Districts in Limpopo and in other provinces in South Africa could produce useful findings. VCT training for counsellors should include the different factors affecting their interaction with young adults, such as maintenance of confidentiality, privacy and use of friendly services. This will help in the provision of quality VCT services that are useful and friendly to VCT users, including young adults. VCT counsellors should always ensure that their practice is based within the legal framework which spells out how healthcare solutions should be offered. Young adults should always be taken as partners in VCT services and their perceptions addressed.

\section{Conclusion}

The study showed that the programme for VCT is perceived as being beneficial to young adults and all the other members in the community, but was believed to be affected by factors such as a lack of resources in areas where young adults are found. The VCT counsellors consequently experienced frustration and emotional burnout related to the VCT programme. A problem that needs to be addressed is that the VCT programme is affected by a lack of standardisation in South Africa - another possible reason for low uptake of services amongst young people.

\section{Acknowledgements Competing interests}

The authors declare that they have no financial or personal relationship(s) which may have inappropriately influenced them in writing this article.

\section{Authors' contributions}

P.R.R. (University of Venda) was the doctoral student responsible for the study. M.D-M. (North West University) was a promoter of the study, as was C.L.O. (University of Kwazulu Natal).

\section{References}

ANOVA Health Institute, 2012, HIVSA certified training for counsellors - Anova Health Institute, viewed 10 January 2012, from www.anovahealth.co.za/projects/entry/ hivsa_certified_training_for_counsellors/

Baggaley, R., 2001, The impact of voluntary counselling and testing: A global review of the benefits and challenges, viewed 29 June 2013, from http://data.unaids.org/ Publications/IRC-pub02/jc580-vct_en.pdf

Brink, H.L., 1996, Fundamentals of Research Methodology for Professionals, Juta: Health Care, Cape Town.

Boswell, D. \& Baggaley, R., 2002, Voluntary counselling and testing: A reference guideResponding to the needs of young people, children, pregnant women and their partners, Family Health International, Arlington, VA.

Burns, N. \& Grove, S.K., 2007, The practice of nursing research: conduct, critique, and utilization, 5th edn., W.B. Saunders Company, Philadelphia.
Carpenter, C.C., Cooper, D.A., Fischl, M.A., Gatell, J.M., Gazzard, B.G., Hammer, S.M. et al., 'Antiretroviral therapy in adults: updated recommendations of the International AIDS Society-USA Panel', JAMA, 283(3), 381-390. http://dx.doi. org/10.1001/jama.283.3.381, PMid:10647802

Cormack, D., 1996, Research Process in Nursing, 3rd edn., Blackwell, London.

Creswell, J.N., 1996, Qualitative inquiry and Research Design: Choosing among Five Approaches, Sage, Thousand Oaks.

Dorrington, R.E., Bradshaw, D. \& Budlender, D., 2002, HIV/AIDS profile of the provinces of South Africa indicators for 2002, Centre for Actuarial Research, Medical Research Council, Actuarial Society of South Africa, viewed 28 June 2013, from http://www.mrc.ac.za/bod/AIDSindicators2002.pdf

Dorrington, R.E., Johnson, L.F., Bradshaw, D. \& Daniel, T., 2006, The Demographic Impact of HIV/AIDS in South Africa. National and Provincial Indicators for 2006 Centre for Actuarial Research, South African Medical Research Council and Actuarial Society of South Africa, Cape Town.

Efuntoye, M., Okonkwo, O., Omorgeie, G. \& Musa, B., 2008, 'Increasing access to HIV counselling and testing: A demonstration project trialling the greater involvement of people living with HIV/AIDS (GIPA) in the workplace', Abstract TUZX0405, XVII International AIDS Conference, Mexico City, Mexico, 3-8th August.

Family Health International (FHI), 2006, Population and reproductive health - HIV/ AIDS and sexual reproductive health linkages, viewed 09 May 2011, from http// go.worldbank.org/Z4RFY3SFCPO

Family Health International (FHI) and USAID, 2003, VCT Toolkit - Voluntary counselling and testing for HIV: a strategic framework, viewed 30 July 2013, from http:// aidsdatahub.org/dmdocuments/Voluntary_Counseling_and_Testing_for_HIV_A Strategic_Framework.pdf.pdf

Field, P.A. \& Morse, J.M., 1996, Nursing Research: The Application of Qualitative Approaches, 2nd edn., Stanley Thornes (Publishers) Ltd, Cheltenham.

Fraenkel, J.R \& Wallen, N.E., 2006, How to design and evaluate research in education, 6th edn., McGraw-Hill Higher Education, London.

Fylkesnes, K., Musonda, R., Sichone, M., Ndhlovu, Z., Tembo, F., Monze, M. et al. 2000 , 'Favourable changes in the HIV epidemic in Zambia in the 1990s', Presented at the 11th International Conference on AIDS and STDs in Africa, Lusaka, Zambia, 12-16th September.

Glesne, C. \& Peshkin, A., 1992, Becoming qualitative researchers: An introduction Longman Publishers, White Plains, NY.

Global Fund, 2013, Fighting AIDS -the global fund to fight AIDS, tuberculosis and malaria, viewed 25 July 2013, from http://www.theglobalfund.org/en/about/ malaria, viewed
diseases/hivaids/

Health Systems Trust, 2001/02, Annual Report 2001/02. Working for today's health system: South Africa's future, viewed 20 April 2011, from http//www.hst.org. za.key-references

International Federation of Red Cross and Red Crescent Societies (IFRC), 2001, Action with Youth. HIV/AIDS and STD: A training manual for young people, 2nd edn., International Federation of Red Cross and Red Crescent Societies, Geneva.

International Planned Parenthood Federation, 2005, Integrating HIV voluntary counselling and testing services into reproductive health settings, Joint publication of IPPF South Asia Regional Office and UNPFA, viewed 10 May 2011, from http// www.unfpa.org/swp/2005/English/notes page8.htm

Jesani, A. \& Barai, T., 2000, Ethical Guidelines for Social Science Research in Health CEHAT, Mumbai, viewed 30 July 2013, from http://www.cehat.org/go/uploads/ EthicalGuidelines/ethicalguidelines.pdf

Kalichman, S.C. \& Simbayi, L.C., 2003, 'HIV testing attitudes, AIDS stigma, and voluntary HIV counselling and testing in a black township in Cape Town, South Africa', Sexually Transmitted Infections 2003/79, 442-447. http://dx.doi.org/10.1136/sti.79.6.442, PMCid:PMC1744787

Kasonda, E. \& DeCelle, K., 2008, A report of a study on improving VCT, ARV and PMTCT services at Embangweni and David Gordon memorial hospitals, viewed 15 April 2011, from http//ddecelle.com/resources/PMTC ServicesatEmbangweniandDavidGordonMemorialHospitals

Koopman, C., Gore-Felton, C., Marouf, F., Butler, L.D., Field, N., Gill, M. et al., 2000, 'Relationships of perceived stress to coping, attachment and social support among HIV-positive persons', AIDS Care 12(5), 663-672. http://dx.doi. org/10.1080/095401200750003833, PMid:11218551

Lincoln, Y.S. \& Guba, E.G., 1985, Naturalistic inquiry, Sage Publications, Beverly Hills.

Maman, S., Mbwambo, J., Hogan, N.M., Kilonzo, G.P. \& Sweat, M., 2001, 'Women's barriers to HIV-1 testing and disclosure: Challenges for HIV-1 voluntary counselling and testing', AIDS Care 13(5), 595-603. http://dx.doi. org/10.1080/09540120120063223, PMid:11571006

Mfundisi, C., Chiranjan, N., Rodrigues, C., Kirchner, L., Bock, P. \& Myer, L., 2005 'Availability of antiretroviral therapy is associated with increased uptake of HIV testing services', South African Medical Journal 95(7), 483-485. PMid:16156445

Mouton, J., 1996, Understanding social research, Van Schaik Publishers, Pretoria.

Mouton, J. \& Marais, H.C., 1998, Basic concepts in the methodology of social science, Van Schaik Publishers, Pretoria.

Nyanzi-Wakholi, B., Lara, A.M., Watera, C., Munderi, P., Gilks, C. \& Grosskurth, H., 2009, 'The role of HIV testing,counselling, and treatment in coping with HIV/ AIDS in Uganda: A qualitative analysis', AIDS Care 21(7), 903-908. http://dx.doi. org/10.1080/09540120802657498, PMid:20024747

Phillips, L.J., 1995, 'HIV and ethics', viewed 30 May 2011, from http://www.hawaii. edu/hivandaids/HIV\%20and\%20Ethics.pdf 
Polit, D.F. \& Hungler, B.P., 1999, Nursing Research: Principles and Methods, 6th edn. Lippincott, Philadelphia, PA. PMid:10482253

Pronyk, P.M., Kim, J.C., Makhubele, M.B., Hargreaves, J.R., Mohlala, R. \& Hausler, H.P. 2002 , 'The introduction of voluntary counselling and rapid testing for HIV in rural South Africa -from theory to practice', AIDS Care 14(6), 859-865. http://dx.doi.or $\mathrm{g} / 10.1080 / 0954012021000031921$, PMid:12511218

Richards, K.A.M., Zivave, A.T., Govere, S.M., Mphande, J. \& Dupwa, B., 2012, 'Counseling in Zimbabwe: history, current status and future trends', Journal of Counseling and Development 90(1), 102-106. http://dx.doi.org/10.1111/j.15566676.2012.00014.x

Rubin, H.J. \& Rubin, I.S., 2006, Qualitative interviewing: The art of hearing data, 2nd edn., Sage Publications, Thousand Oaks, CA.

Sherr, L., Bergenstrom, A. \& Hudson, C.N., 2000, 'Consent and antenatal HIV testing: The limits of choice and issues of consent in HIV and AIDS', AIDS Care 12(3), 307312. http://dx.doi.org/10.1080/09540120050042963, PMid:10928208

Skinner, D. \& Mfecane, S., 2004, 'Stigma, discrimination and the implications for people living with HIV/AIDS in South Africa', Journal of Social Aspects of HIV \& AIDS 1(3), 157-164. http://dx.doi.org/10.1080/17290376.2004.9724838, PMid:17601003
Strachan, M., Kwateng-Addo, A., Hardee, K., Subramanian, S., Judice, N. \& Agarwal, K., 2004, An analysis of family planning content in HIV/AIDS, VCT and PMTCT policies in 16 countries, POLICY working paper series No. 9, viewed 30 July 2013, from http://pdf.usaid.gov/pdf_docs/Pnacx558.pdf

Streubert, H.J. \& Carpenter, D.R., 1999, Qualitative research in nursing advances: the humanistic imperative, Lippincott, Philadelphia.

Strydom, H., 2002, 'Ethical aspects of research in the social sciences and human services professions', in A.S. de Vos, H. Strydom, C.B. Fouche \& C.S.L. Delport (eds.), Research at Grassroots: a primer for the social sciences and human service professions, pp. 62-76, Van Schaik Publishers, Pretoria

UNICEF in Action, 2003, Fighting HIV/AIDS: Strategies for success, viewed 15 August 2005, from http://www.unicef.org/programme/hiv/focus/mtct/hiv.htm

USAID/Family Health International, 2004, VCT Toolkit. HIV voluntary counselling and testing: A reference guide for counsellors and trainers, USAID, Addis Ababa.

WHO/UNAIDS/UNICEF, 2010, Towards universal access: Scaling up priority HIV/AIDS interventions in the health sector, viewed 30 July 2013, from http://www.who.int/ pub/2010progressreport/en/ 